\title{
Factors Influencing Habitat Selection of Three Cryptobenthic Clingfish Species in the Shallow North Adriatic Sea
}

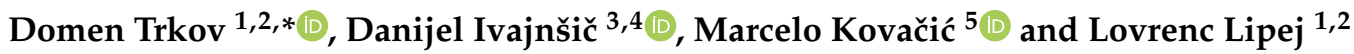 \\ 1 Marine Biology Station Piran, National Institute of Biology, Fornače 41, 6330 Piran, Slovenia; \\ lovrenc.lipej@nib.si \\ 2 Jožef Stefan Institute and Jožef Stefan International Postgraduate School, Jamova Cesta 39, \\ 1000 Ljubljana, Slovenia \\ 3 Faculty of Natural Sciences and Mathematics, University of Maribor, Koroška Cesta 160, \\ 2000 Maribor, Slovenia; dani.ivajnsic@um.si \\ 4 Faculty of Arts, University of Maribor, Koroška Cesta 160, 2000 Maribor, Slovenia \\ 5 Natural History Museum Rijeka, Lorenzov Prolaz 1, 51000 Rijeka, Croatia; marcelo@prirodoslovni.com \\ * Correspondence: domen.trkov@nib.si
}

Citation: Trkov, D.; Ivajnšič, D.;

Kovačić, M.; Lipej, L. Factors

Influencing Habitat Selection of Three Cryptobenthic Clingfish Species in the Shallow North Adriatic Sea. J. Mar. Sci. Eng. 2021, 9, 789. https:// doi.org/10.3390/jmse9080789

Academic Editor:

Jorge M.S. Gonçalves

Received: 15 June 2021

Accepted: 17 July 2021

Published: 22 July 2021

Publisher's Note: MDPI stays neutral with regard to jurisdictional claims in published maps and institutional affiliations.

Copyright: (C) 2021 by the authors Licensee MDPI, Basel, Switzerland. This article is an open access article distributed under the terms and conditions of the Creative Commons Attribution (CC BY) license (https:// creativecommons.org/licenses/by/ $4.0 /$ )

\begin{abstract}
Cryptobenthic fishes were often overlooked in the past due to their cryptic lifestyle, so knowledge of their ecology is still incomplete. One of the most poorly studied taxa of fishes in the Mediterranean Sea is clingfish. In this paper we examine the habitat preferences of three clingfish species (Lepadogaster lepadogaster, L. candolii, and Apletodon incognitus) occurring in the Gulf of Trieste (Northern Adriatic). The results show that all three species have a cryptic lifestyle and are wellsegregated based on their depth distribution and macro- and microhabitat preferences. L. lepadogaster inhabits shallow waters of the lower mediolittoral and upper infralittoral, where it occurs on rocky bottoms under stones. L. candolii similarly occurs in the rocky infralittoral under stones, but below the lower distribution limit of L. lepadogaster, and in seagrass meadows, where it occupies empty seashells. Such hiding places in seagrass meadows are also occupied by $A$. incognitus, which mostly occurs below the lower distribution limit of $L$. candolii. Despite the overlap of depth and macrohabitat, the probability of individuals of two species encountering each other or competing in the same habitat is low when the depth range is combined with the microhabitat preferences of these species.
\end{abstract}

Keywords: cryptobenthic fish; clingfish; habitat selection; depth distribution; Lepadogaster lepadogaster; Lepadogaster candolii; Apletodon incognitus

\section{Introduction}

Knowledge of species habitat preferences is essential, since it provides basic information about the suitability of the environment for a particular species [1]. Habitat preferences are important species traits that have many ecological consequences, ranging from the fitness of individuals $[2,3]$ to the abundance and distribution of species in the environment [4]. As habitats can be diverse, with numerous variables shaping them, it can be quite challenging to determine the critical factors that affect habitat preferences [5]. The individual chooses the habitat that positively affects its fitness by providing a sufficient amount of adequate food [6] or allowing the possibility of increased survival due to reduced predation and mortality risk [7]. Such habitat choice is known especially in cryptobenthic fish species, based on Miller's definition [8] as those whose "small body size permits exploitation of restricted habitats, where food and shelter are obtained in, or in relation to, conditions of substrate complexity and/or restricted living space, with a physical barrier likely to be interposed between the small fish and sympatric predators". Consequently, by exhibiting such a cryptic lifestyle, fish are hardly observed by divers and are usually not detected in conventional ichthyofaunal surveys [9]. Smith-Vaniz et al. [10] concluded that around 64\% of fish fauna can be overlooked by visual censuses due to their hiding habits. Therefore, 
knowledge about the occurrence and ecology of cryptobenthic fishes remains fragmented at a global scale. Recent studies have shown that cryptobenthic fish species are not rare, as previously assumed [11], but rather common [12-14]. Ackerman and Bellwood [15] proved that cryptobenthic fishes from tropical reefs, due to their high abundance, can potentially influence the ecosystem. Recently, many authors have reported the importance (e.g., energy transfer) of cryptobenthic fish species in tropical seas (e.g., [15-17]), while there is still a lack of knowledge on cryptobenthic fish species from the Mediterranean and their ecology $[13,18]$.

One of the less-studied taxa of fishes in the Mediterranean Sea is clingfish (family Gobiesocidae) [12,13]. Clingfish, all species of which are cryptobenthic, are poorly known due to their small size, cryptic way of life, good camouflage, and the fact that only a few ichthyologists have worked on this family [19]. Furthermore, since they are cryptobenthic, it is not possible to collect specimens with common methods (e.g., nets or baited traps) [19]; collection requires scuba equipment and the use of anesthetic. The aim of this study is to provide information on the habitat preferences of three clingfish species (Lepadogaster lepadogaster (Bonnaterre 1788), L. candolii (Risso 1810), and Apletodon incognitus (Hofrichter and Patzner 1997)) in the Gulf of Trieste. L. lepadogaster and L. candolii, despite being poorly studied, are the most common species of European clingfishes (family Gobiesocidae) and are widespread throughout Mediterranean Sea and, also, in the Eastern Atlantic coast from England to Northwest Africa, the Canary Islands, and the Madeira Islands [9,20-28]. A. incognitus is a recently described species $[29,30]$ with poorly known biology and ecology. The species presence has been confirmed for the northern part of the Mediterranean Sea, including the Adriatic Sea, and in the Eastern Atlantic at the Azores Islands [29,31,32].

\section{Materials and Methods}

\subsection{Study Area}

The study was conducted in the Slovenian part of the Gulf of Trieste, the northernmost part of both the Adriatic and Mediterranean Seas. The Gulf of Trieste is a shallow gulf $(20-25 \mathrm{~m})$ isolated from the rest of the Northern Adriatic and restricted by a transect from Grado to Savudrija Peninsula. It occupies an area of about $500 \mathrm{~km}^{2}$ [33]. The seabed of the Slovenian Sea is a predominantly soft sedimentary bottom of fluvial origin, while the coastal bottom is mostly rocky, consisting mainly of Eocene Flysch layers. The coastal bottom consists of boulder fields and banks of pebbles, where the sizes of the boulders, rocks, stones, and substrate particles decrease with the distance from the shore. The rocky bottom extends to a depth of about $10 \mathrm{~m}$, where it changes to a sedimentary bottom. Inside bays, soft sedimentary bottoms of fluvial origin prevail [33]. On the shallow costal sedimentary bottom, seagrass meadows appear between 1- and 11-m depths [34].

\subsection{Data Collection}

\subsubsection{Field Work}

Sampling of clingfish specimens was performed from October 2016 to March 2019. In addition, 166 specimens of $A$. incognitus and 9 specimens of $L$. candolii from the collection of the Marine Biology Station Piran, National Institute of Biology (Piran, Slovenia) collected from 2005 to 2008 were included in the research. Samplings were performed at different localities in the coastal waters of the Slovenian part of the Gulf of Trieste. Altogether, 206 samplings (approximately $1 \mathrm{~h}$ each) were performed within 72 locations (Figure 1) that were randomly selected. Clingfishes were found within 107 sampling sites. 


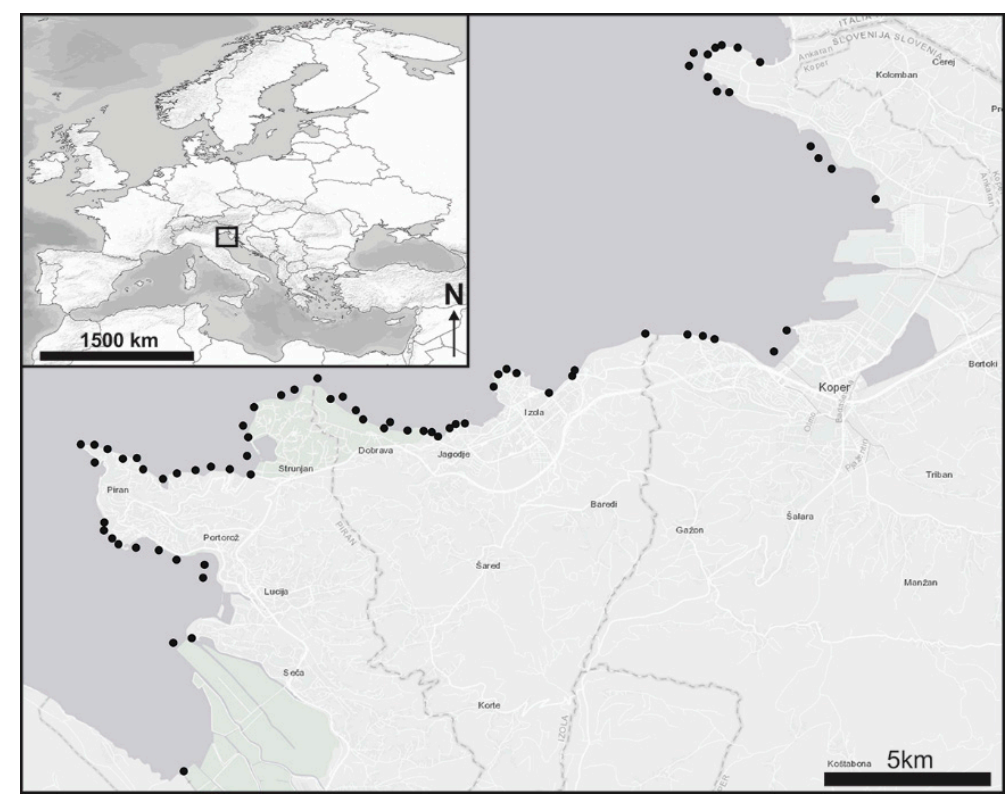

Figure 1. Sampling locations (black dots) along the Slovenian coastline where clingfishes were searched.

Specimens were collected by snorkeling and scuba diving in mediolittoral (41 sampling locations) and infralittoral belts (31 sampling locations). Additionally, some specimens were collected in tide pools during low tide. The main types of habitats studied were as follows: (a) Sandstone boulder fields, consisting of arrangements of sandstone boulders and mostly rectangular-shaped stones in one layer of bedrock extending from the mediolittoral to approximately $10 \mathrm{~m}$. (b) Banks of pebbles, occurring mostly in protected bays. Sandstone pebbles were flatter, while limestone pebbles were rounded. Pebbles were arranged in layers, with larger pebbles $(3-10 \mathrm{~cm})$ on the surface and smaller pebbles $(1-3 \mathrm{~cm})$ in the deeper layers. Banks of pebbles were present mostly in mediolittoral and upper infralittoral. (c) Seagrass meadows of Cymodocea nodosa and Posidonia oceanica, where clingfish were sought in rhizomes (matte) and seashells in particular. (d) Sandy-muddy bottoms.

\subsubsection{Fish Collection}

Fish were randomly sought in different hiding places, such as under stones, boulders, and shells, or inside natural cavities such as caves, cavities, holes, clefts, etc. To facilitate the collection, the narcotic quinaldine (Sigma-Aldrich, St. Louis, MO, USA) diluted to 1:15 solution with alcohol $[12,35]$ was used. The narcotic was sprayed into the hiding places using a laboratory wash bottle. The anesthetized fish were then caught with a hand net. Specimens of L. lepadogaster were also collected without anesthetic by lifting stones and catching them with the hand net. Specimens that were attached to the lower surface of the stones dropped themselves right into the net. Specimens of $A$. incognitus sighted in oyster shells were captured by placing a plastic bag over the oyster shell and chasing them into the bag. In the case of clingfish species, we also checked the hiding places to see if there were nests inside them. We also sampled banks of pebbles in the mediolittoral and upper infralittoral with a bucket and checked for fish with a sieve [36]. After sampling, stones and rocks that were checked for the presence of cryptobenthic fishes were placed in their former position, so that we did not cause damage to the natural habitat. Clingfishes were caught and stored in 100-mL plastic chambers with small holes in the cover that provided fresh water with oxygen. 


\subsubsection{Habitat Survey}

Basic ecological data on the sampling location were obtained at each site. We collected the date and location; end environmental variables: macrohabitat (e.g., rocky area, sediment bottom, and seagrass meadow) and microhabitat (e.g., under stones and in seashells); and depth of finding.

Since 2 species were hiding under stones, they were analyzed in more detail to determine the differences in their habitat preferences. To this end, we measured the length, width, and height of stones and collected data on the presence of algal and sponge overgrowth on the stones and particular substrate under the stones. When mediolittoral sampling was done, the depth was calculated based on the depth of the sampling point and the zero point from the tide amplitude calendar [37-39].

\subsubsection{Laboratory Work}

After sampling, fish were transferred as soon as possible (less than $1 \mathrm{~h}$ after sampling was completed) to Marine Biology Station Piran (MBS) of the National Institute of Biology, where they were photographed with an Olympus TG-4 (Olympus, Tokyo, Japan) and cautiously measured to the nearest $0.01 \mathrm{~mm}$ with a caliper. The sex of the clingfish specimens was determined based on the length and size of the urogenital papillae, which are larger and more elongated in males than in females [18,24], while, in A. incognitus, the sex was also determined based on the size of caniniform teeth, which are larger in males [18]. Fish were identified at the species level by using the identification keys of Jardas [40] and Marčeta [41] and by scientific articles with species diagnoses, descriptions, and keys for identification $[9,19,29,42]$. After laboratory examination, the clingfish specimens were released at the sites where they were collected.

\subsubsection{Data Analysis}

During the survey, altogether, 641 clingfish specimens were recorded in the field, and 419 of them were measured (194 specimens of L. lepadogaster, 177 specimens of L. candolii, and 108 specimens of $A$. incognitus). In the next step, the sex ratio was calculated for each species. Potential differences in the sex structure within species were tested with chi-square $\left(\chi^{2}\right)$ statistics $(\alpha=0.05)$ in R statistical software (R Foundation for Statistical Computing, Vienna, Austria) [43]. Water depth recordings for the observed sample $(N=419)$ enabled a depth distribution comparison between species. Here, ANOVA and the corresponding Tukey's post hoc test were applied. Since the studied fish species prefer different pebble morphology, the stone dimensions (length, width, and height) where the fish were caught were measured. These data were then used to calculate the stone volume and shape (flatness). The latter was determined by applying the ratio of the surface area to the volume (SA:V $=\mathrm{S} / \mathrm{V}$, where $\mathrm{S}$ is surface $\left(\mathrm{cm}^{2}\right)$ and $\mathrm{V}$ is volume $\left(\mathrm{cm}^{3}\right)$ ). The higher the ratio, the flatter the stone. In the next step, a linear regression analysis in the $\mathrm{R}$ statistical environment [43] was used to compare the influence of combinations of the habitat factors on the studied fish species: depth distribution and fish size, undersurface area of the stone and fish size, and flatness $(\mathrm{SA}: \mathrm{V})$ of the stone and depth distribution.

\section{Results}

\subsection{Size Distribution and Sex Ratio of Three Species}

The sizes of the L. lepadogaster specimens ranged from 28.06 to $78.02 \mathrm{~mm}$ $(57.60 \pm 8.54 \mathrm{~mm})$. The sex ratio of 182 specimens of L. lepadogaster whose sex was determined (others were immature) showed no statistical differences $\left(\chi^{2}=2.66 ; \mathrm{df}=1 ; p>\alpha\right.$; $\alpha=0.05)$, although the ratio was 1:1.3 in favor of males. The average male size was measured as $59.8 \mathrm{~mm}$, and the maximum size was $78.02 \mathrm{~mm}$ in total length, while the average female size was $55.7, \mathrm{~mm}$ and they reached $72.12 \mathrm{~mm}$ in total length.

The size of the L. candolii specimens ranged from 13.97 to $86.94 \mathrm{~mm}(41.48 \pm 16.00 \mathrm{~mm})$ in total length. The sex ratio calculated from 56 specimens whose sex was determined (others were immature) did not statistically differ from 1:1 $\left(\chi^{2}=12.07 ; \mathrm{df}=1 ; p<\alpha\right.$; 
$\alpha=0.05$ ) and was 1:2.7 in favor of females. Males measured an average of $64.2 \mathrm{~mm}$ and reached a maximum of $86.94 \mathrm{~mm}$ in total length, while females measured an average of $52.4 \mathrm{~mm}$ and reached a maximum $66.08 \mathrm{~mm}$ in total length.

The size of $A$. incognitus specimens ranged from $12.24 \mathrm{~mm}$ to a maximum of $50.69 \mathrm{~mm}$ $(31.16 \pm 9.40 \mathrm{~mm})$ in total length. The sex ratio calculated from 66 specimens whose sex was determined was statistically different from $1: 1\left(\chi^{2}=8.72 ; \mathrm{df}=1 ; p<\alpha ; \alpha=0.05\right)$ and was 1:2.1 in favor of males. Males measured an average of $36 \mathrm{~mm}$ and reached a maximum of $50.69 \mathrm{~mm}$ in total length, while females measured an average of $22 \mathrm{~mm}$ and reached a maximum of $29.35 \mathrm{~mm}$ in total length.

\subsection{Habitat Preferences of Lepadogaster lepadogaster}

All 242 specimens of L. lepadogaster were found in the exposed or partially exposed rocky coastal area and were absent in sheltered areas. Specimens occurred between $0.4-$ and 2.2-m depths, with 75\% of specimens found between 0.7 and $1.2 \mathrm{~m}$. The results showed a positive correlation $(p<\alpha ; \alpha=0.05)$ between the fish size and sea depth of fish occurrence. Most of them were found in boulder fields and banks of larger stones, where they were hiding under stones (98.3\%), while a few specimens were found hiding in banks of pebbles. The specimens were mostly attached to the smooth and bare undersides of stones. In only a few cases, they were present under stones on the substrate. The average sizes of stones under which specimens were found were $26.0( \pm 11.0) \times 14.3( \pm 5.7) \times 7.6( \pm 4.0) \mathrm{cm}$ (length $\times$ width $\times$ height), with an average bottom surface of $409.8 \pm 349 \mathrm{~cm}^{2}$, while the average volume of the stones was $4027.7 \pm 8269.4 \mathrm{~cm}^{3}$. The bottom surface area positively influenced the clingfish size, as large specimens preferred stones with larger surface areas ( $t$-test, $p<\alpha ; \alpha=0.05)$. Furthermore, our data showed a significant negative linear relation $(p<\alpha ; \alpha=0.05)$ between stone flatness (SA:V) and depth of occurrence, showing that occupied stones were flatter with the decreasing depth. Stones were mostly overgrown with turf vegetation $(58.4 \%)$ or were bare $(36.6 \%)$. Under stones where clingfishes were found, the most common substrate was pebbles $(63.8 \%)$, which were sometimes mixed with sand $(20.4 \%)$ or rarely occurred together with a sandstone terrace. The pebbles under stones were of different sizes and rectangular in shape and mostly in one layer. Only rarely was the substrate made of a sandstone terrace $(7.2 \%)$. In seven cases, more than one specimen was found under the same stone.

\subsection{Habitat Preferences of Lepadogaster candolii}

During the survey, 177 specimens of L. candolii were observed in the field. Specimens were found from 0.7 - to 5.3-m depths, mostly (75\%) in the depth range from 1.8 to $3.3 \mathrm{~m}$. Four specimens were also found in tide pools. The results showed a significant negative linear relation $(p<\alpha ; \alpha=0.05)$ between fish size and depth occurrence, as large specimens occurred in shallower waters and small specimens occurred somewhat deeper. Specimens were mostly found in the rocky coastal area $(82.5 \%)$ in boulder fields and under solitary rocks on sand patches, while $17.5 \%$ of them were found in a seagrass meadow of $C$. nodosa and P. oceanica. Specimens were mostly attached to the underside of objects (such as stones and seashells) or were sometimes present in the substrates under objects. Specimens were mostly found under stones (90.4\%) and rarely under sandstone terraces, seashells (e.g., Pinna nobilis and Ostrea edulis), or artificial objects (e.g., plastic and metal plates) on the sea bottom. In four cases, juvenile specimens were found outside the shelter on shells of living $P$. nobilis. The average sizes of stones under which specimens were found were $26.9( \pm 12.7) \times 17.1( \pm 7.5) \times 6.7( \pm 4.0) \mathrm{cm}($ length $\times$ width $\times$ height $)$, and they had an average bottom surface of $530.9 \pm 533.1 \mathrm{~cm}^{2}$, while the average volume of the stones was $4487.6 \pm 9655.5 \mathrm{~cm}^{3}$. The obtained data showed that fish sizes increase along the bottom surface area gradient, as larger specimens preferred stones with larger surface areas. Our data showed a positive correlation between depth and stone flatness (SA:V), indicating that stones were flatter with the increasing depth. Furthermore, our data showed a significant linear relation $(p<\alpha ; \alpha=0.05)$ between stone flatness (SA:V) and depth of occurrence. The 
surface on the underside of stones occupied by L. candolii was relatively rough, due to small holes made by different biota, and was also covered with tubes of serpulid polychaetes. Different kinds of small sponges were usually also present on the undersides of the stone surfaces, but their presence was not included in the analyses. All stones were overgrown with algae, $25.3 \%$ of them with algal turf and $62.4 \%$ with macroalgae (e.g., Padina pavonica, Dictyota sp., and Cystoseira sp.). Less often (12.4\%), the stones were also overgrown also with sponges (e.g., Aplysina aerophoba). The most common substrate under the stones was pebbles, which were most often mixed with sand (54.2\%).

\subsection{Habitat Preferences of Apletodon incognitus}

Altogether, 222 specimens were observed during the survey. Specimens were found from 1.6- to 6.6-m depths, mainly $(75 \%)$ in the depth range from 3.45 to $4.5 \mathrm{~m}$. The results showed a significant linear relation $(p<\alpha ; \alpha=0.05)$ between the size and depth occurrence of $A$. incognitus, as large specimens occurred somewhat deeper. Most specimens (98.2\%) were found in a seagrass meadow of $C$. nodosa and only few in a seagrass meadow of P. oceanica. Less than $2 \%$ of specimens were found on the sediment bottom but only in the immediate vicinity of the seagrass meadow. Specimens were found in various hiding places (Figure 2). Specimens occupied mostly dead oyster shells (66.0\%), especially oysters attached to $P$. nobilis (82.8\% of all specimens found in oyster shells), and less often in clusters of oyster shells on the sea bottom ( $9.4 \%$ of all specimens found in oyster shells). Many specimens were also found on living adult $P$. nobilis $(22.2 \%)$ that were overgrown with an epibiota cover (e.g., oysters, bryozoans, serpulid polychaetes, and algae). Only $4.6 \%$ of specimens were found on isolated stones that were present in the seagrass meadow. Smaller juvenile and subadult specimens of $A$. incognitus $(<35 \mathrm{~mm}$, with a narrow head in the cheek area) were often found outside the shelter on shells of living P. nobilis (73.1\% of all specimens found outside $P$. nobilis), while bigger adult specimens ( $>35 \mathrm{~mm}$, with a wide head in the cheek area) were mostly found hiding inside empty oyster shells. Specimens of $P$. nobilis on which specimens of $A$. incognitus were found were mostly adult and did not have spines (a characteristic feature of juvenile noble pen shells), which would disable the clinging ability. Shells of $P$. nobilis were normally overgrown with epibiota, which provided cover for the fish. Disturbed fish sometimes moved to seagrass leaves, but they were never found hiding among the leaves.

\subsection{Comparison of Three Clingfish Species}

\subsubsection{Size Distribution and Sex Ratio}

Although L. candolii reached the largest maximum size of all three species, the specimens were on average smaller than those of L. lepadogaster, while A. incognitus was the smallest. In L. lepadogaster and A. incognitus, males prevailed in the population, while, in L. candolii, females were more abundant. In all three species, males were, on average, larger than females and reached a larger maximum body size.

\subsubsection{Depth Distribution}

All three species were clearly separated based on depth segregation (ANOVA and Tukey's post hoc test; $p<\alpha ; \alpha=0.05$ ) (Figure 3). L. lepadogaster occurred in the shallowest water from the lower mediolittoral to upper infralittoral. The depth distribution of L. lepadogaster in the upper infralittoral (down to a 2-m depth) overlapped with the upper limit of occurrence of $L$. candolii. However, specimens of L. candolii mostly occurred deeper in the infralittoral and were most abundant below the limit of the distribution of L. lepadogaster. Although there was a slight overlap in the depth range with L. lepadogaster, it is necessary to take into account the preference to habitat exposure. In the sheltered bay of St. Jernej (Ankaran), L. lepadogaster was absent, and this was the only location where L. candolii occurred in tide pools, so there was no habitat overlap between the species. However, in exposed or partially exposed locations where both species were present, L. candolii was mostly found below the lower limit of distribution of L. lepadogaster. In only a few cases, 
L. lepadogaster and L. candolii were found together at the border of their occurrence in the upper infralittoral. L. candolii also had an overlap in its lower limit of depth distribution with $A$. incognitus, which occurred in deeper waters than the other two species. However, $L$. candolii occurred mostly above the depth distribution of $A$. incognitus, while there was almost no overlap in the depth distribution between L. lepadogaster and A. incognitus.

In all three species, intraspecific depth segregation based on the sizes of the specimens was observed. Inside the limit of depth distribution, large specimens of L. lepadogaster and A. incognitus were present in deeper water, while juveniles were more abundant in shallow water (Figure 4). Conversely, large specimens of L. candolii were more abundant in shallow water, while juveniles were more abundant deeper inside their depth distribution. Our data confirmed a significant linear relation $(p<\alpha ; \alpha=0.05)$ between fish size and depth occurrence. However, the largest specimens of L. lepadogaster and L. candolii were the most abundant in waters between 1.5 and $2 \mathrm{~m}$, while smaller specimens of L. lepadogaster were more abundant in shallower water, and juveniles of L. candolii were more abundant in deeper water inside their depth distribution. Based on these results, there is a low chance of overlap between large specimens of both species and almost no chance of overlap in the depth distribution between small specimens of these species.

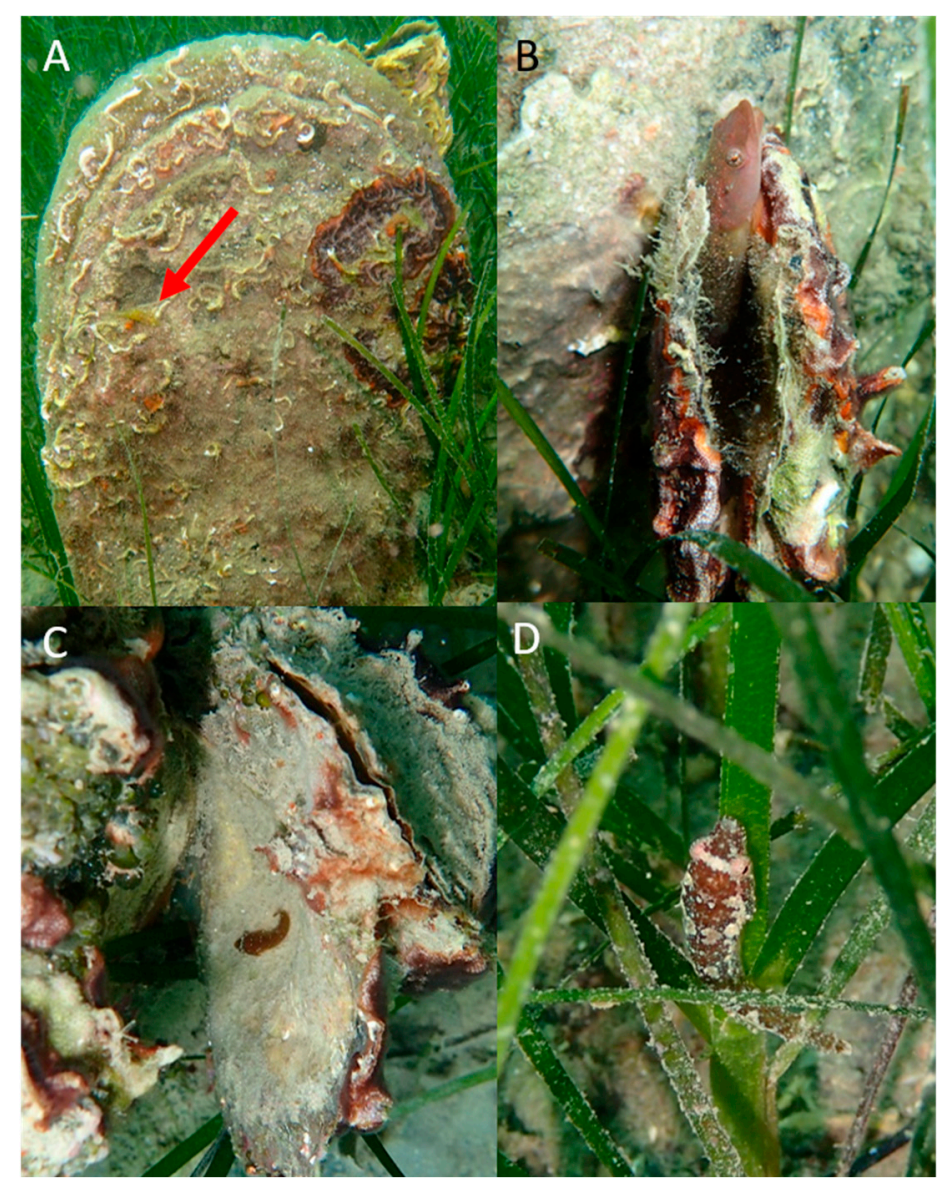

Figure 2. Specimens of hiding Apletodon incognitus: (A) on the shell of Pinna nobilis, (B) nesting male occupying a slightly open dead oyster shell, (C) non-nesting specimen occupying a wide-open dead oyster shell, and (D) disturbed specimen that moved from shelter to seagrass leaf (Photos: D. Trkov.). 


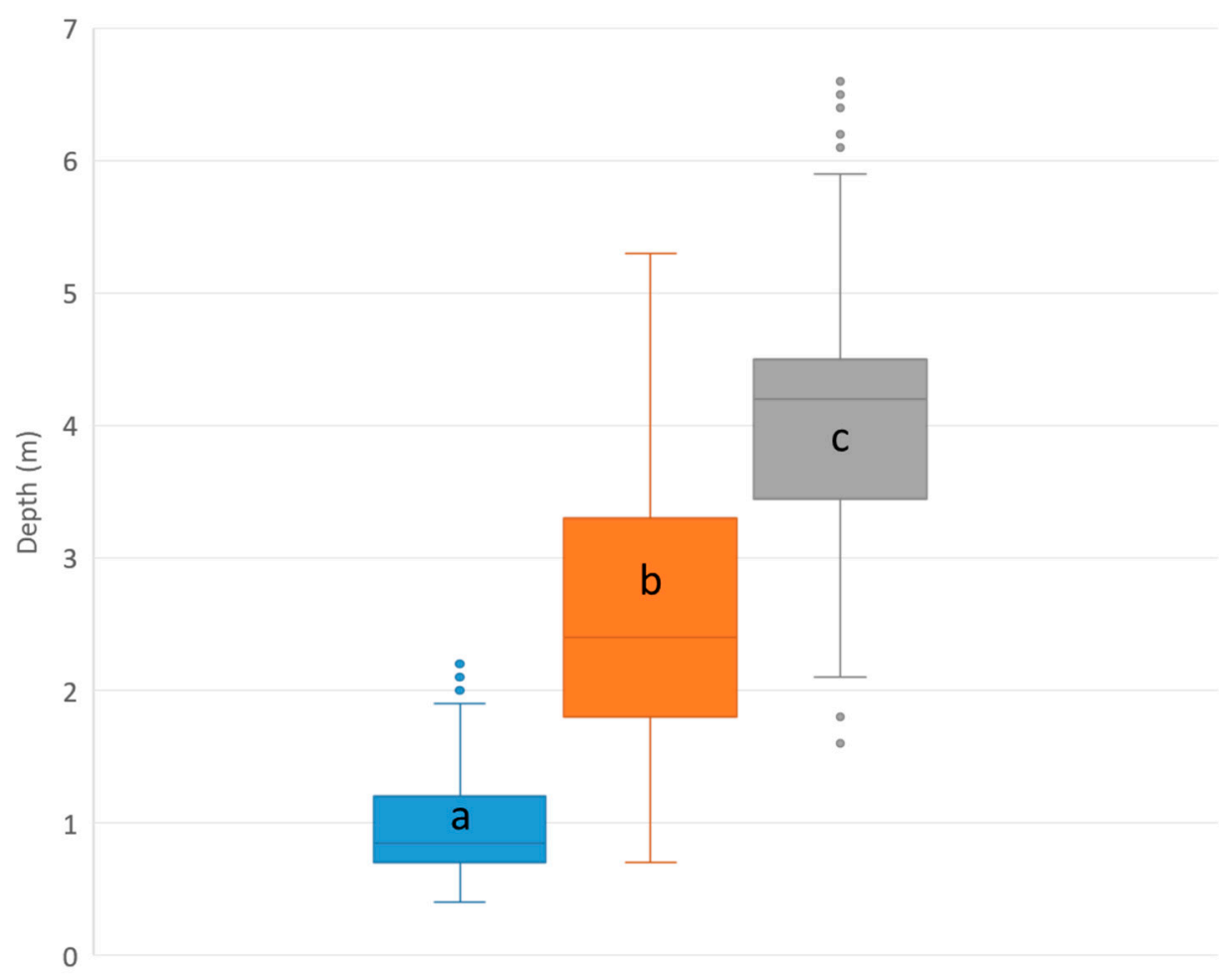

Figure 3. Depth distribution of three clingfish species. There is statistically significant difference (marked: $a, b$ and c) between species based on depth of occurrence (Tukey's post-hoc test). Blue rectangle: Lepadogaster lepadogaster, orange rectangle: Lepadogaster candolii and gray rectangle: Apletodon incognitus.

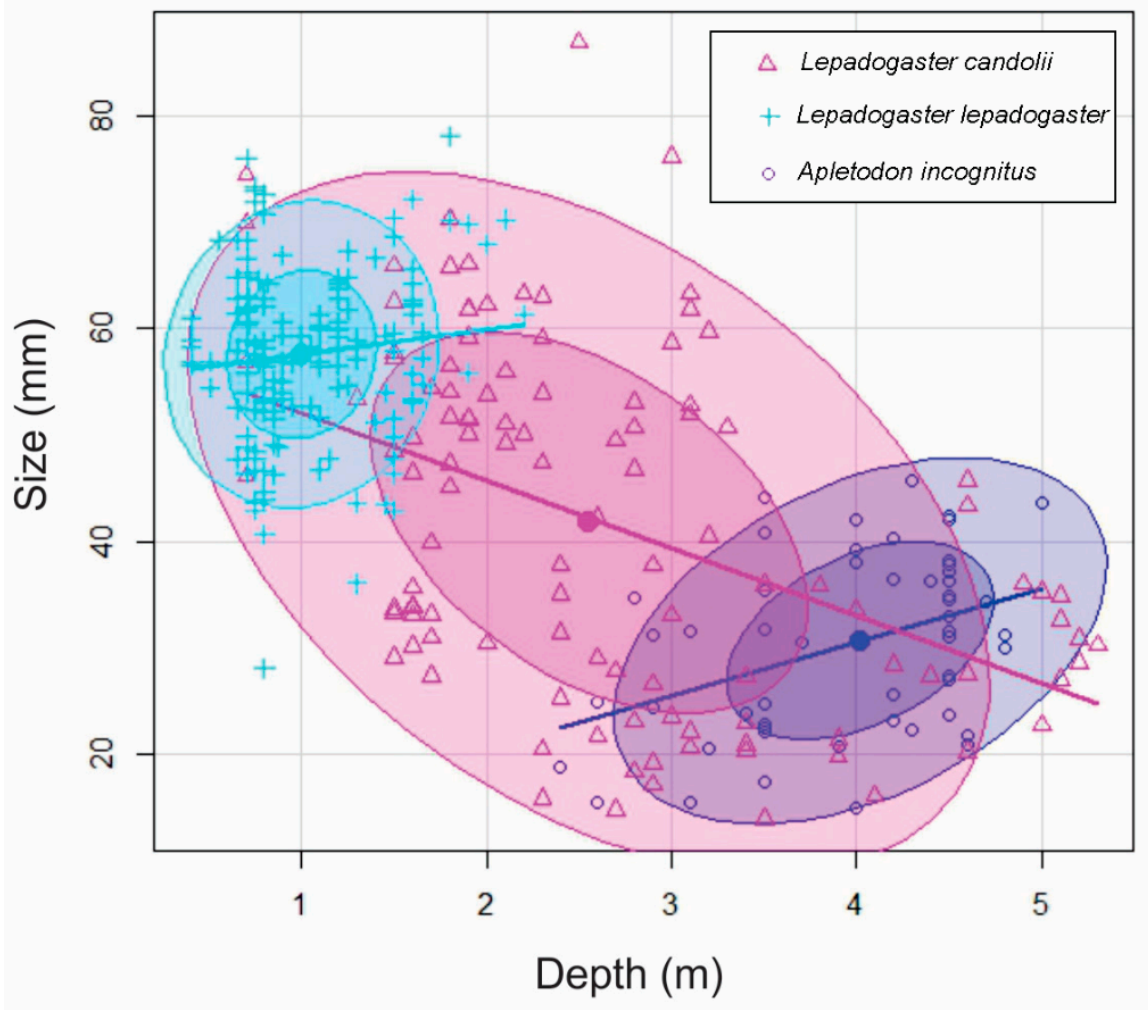

Figure 4. Depth distribution of three clingfish species based on their sizes. Inner concentration ellipses cover $50 \%$ of all data for a given species, and outer concentration ellipses cover $75 \%$ of data for a particular species. 


\subsubsection{Habitat Selection}

The three species showed different macrohabitat preferences. L. lepadogaster and A. incognitus were very specific in their habitat choices. L. lepadogaster was found only in rocky environments, while $A$. incognitus was strictly associated with seagrass meadows (Figure 5), and L. candolii was found in both.

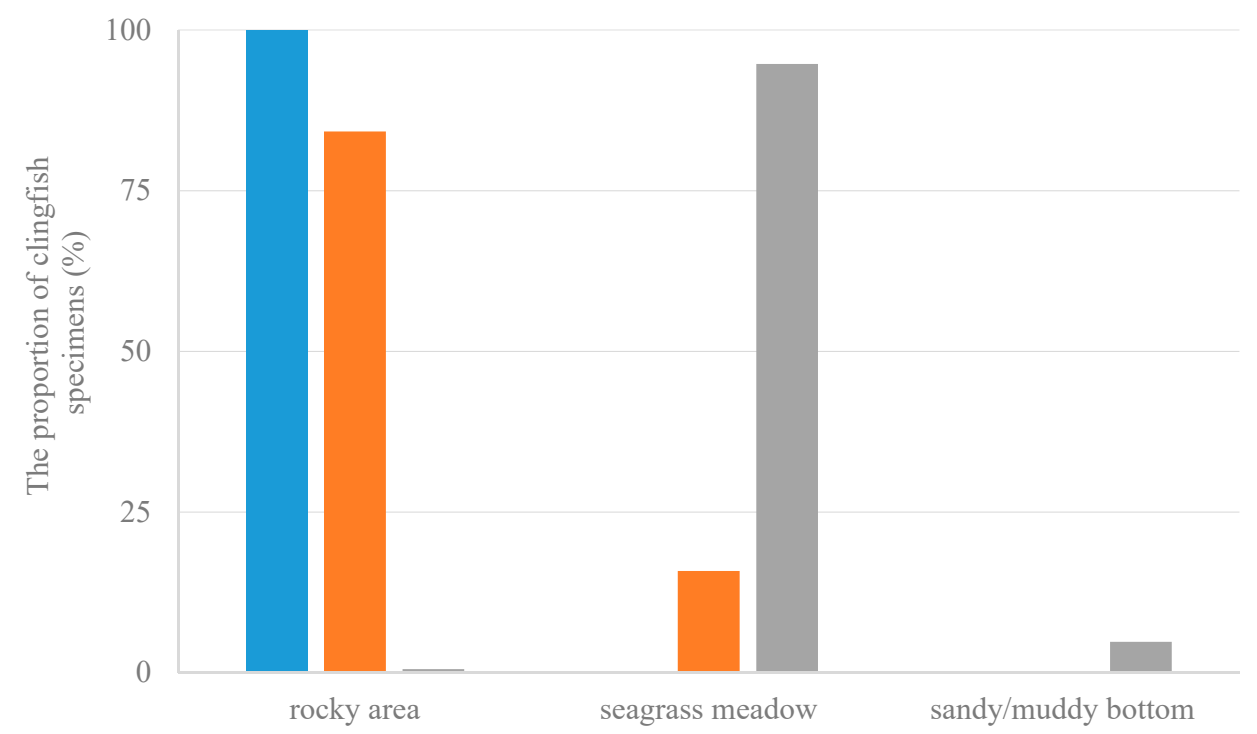

Figure 5. Macrohabitat preferences of three clingfish species. Blue bars: Lepadogaster lepadogaster, orange bars: Lepadogaster candolii, and gray bars: Apletodon incognitus.

The macrohabitat preferences of L. lepadogaster and L. candolii overlapped, with both occurring mostly in the rocky bottom under stones (Figure 6). These were mostly made of sandstones (the characteristic rock type in the area) that were mostly rectangular in shape. Further, the two species showed various differences in microhabitat choices in addition to their depth range. L. candolii occupied stones with larger average undersurface areas (1.3 times larger) than L. lepadogaster, and the stones were flatter, which prevents them from sinking into the sediment; deeper in the infralittoral where L. candolii occurred, a sedimentary bottom (e.g., sand) was present, so only flat stones had not sunk into the sediment. This is further supported by observations that stones occupied by L. candolii were flatter with the increasing depth (Figure 7). A statistically significant difference in the substrate under the occupied stones between L. lepadogaster and L. candolii was found $\left(\chi^{2}=130.59 ; \mathrm{df}=1 ; p<\alpha ; \alpha=0.05\right)$. Pebbles as substrates under stones were typical for L. lepadogaster, while pebbles with sand were typical for L. candolii (Figure 8). A statistically significant difference in overgrown stones between L. lepadogaster and L. candolii was also found $\left(\chi^{2}=228.53 ; \mathrm{df}=1 ; p<\alpha ; \alpha=0.05\right)$. Bare stones and stones with turf vegetation were typical for L. lepadogaster, while stones with macroalgae were typical for L. candolii (Figure 9). 


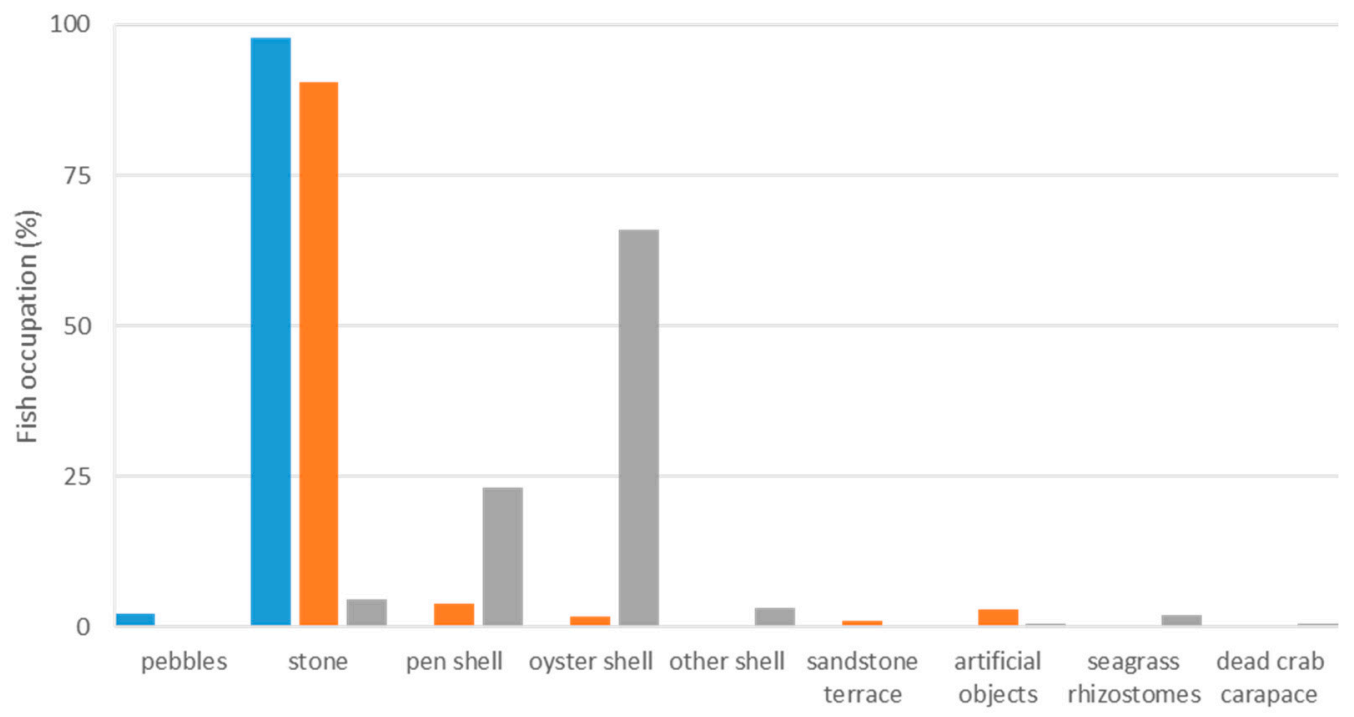

Figure 6. Shelters occupied by three species of clingfish. Blue bars: Lepadogaster lepadogaster, orange bars: Lepadogaster candolii, and gray bars: Apletodon incognitus.

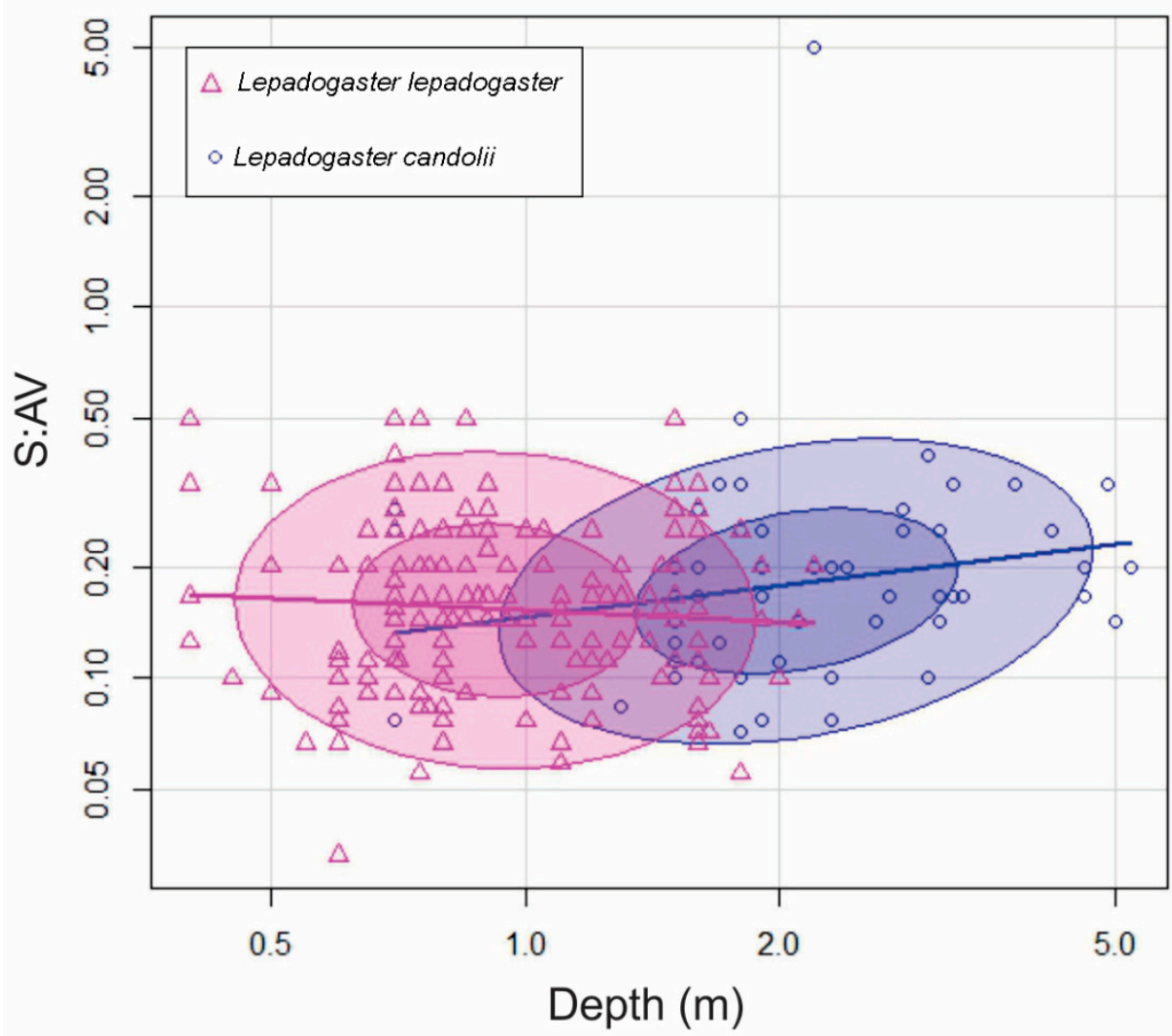

Figure 7. Ratio between the depth and surface area-to-volume ratio $(\mathrm{SA}: \mathrm{V})$ of stones for Lepadogaster lepadogaster and Lepadogaster candolii. Inner concentration ellipses cover $50 \%$ of all data for a given species, and outer concentration ellipses cover $75 \%$ of the data for a particular species. Both axes are log-transformed. 


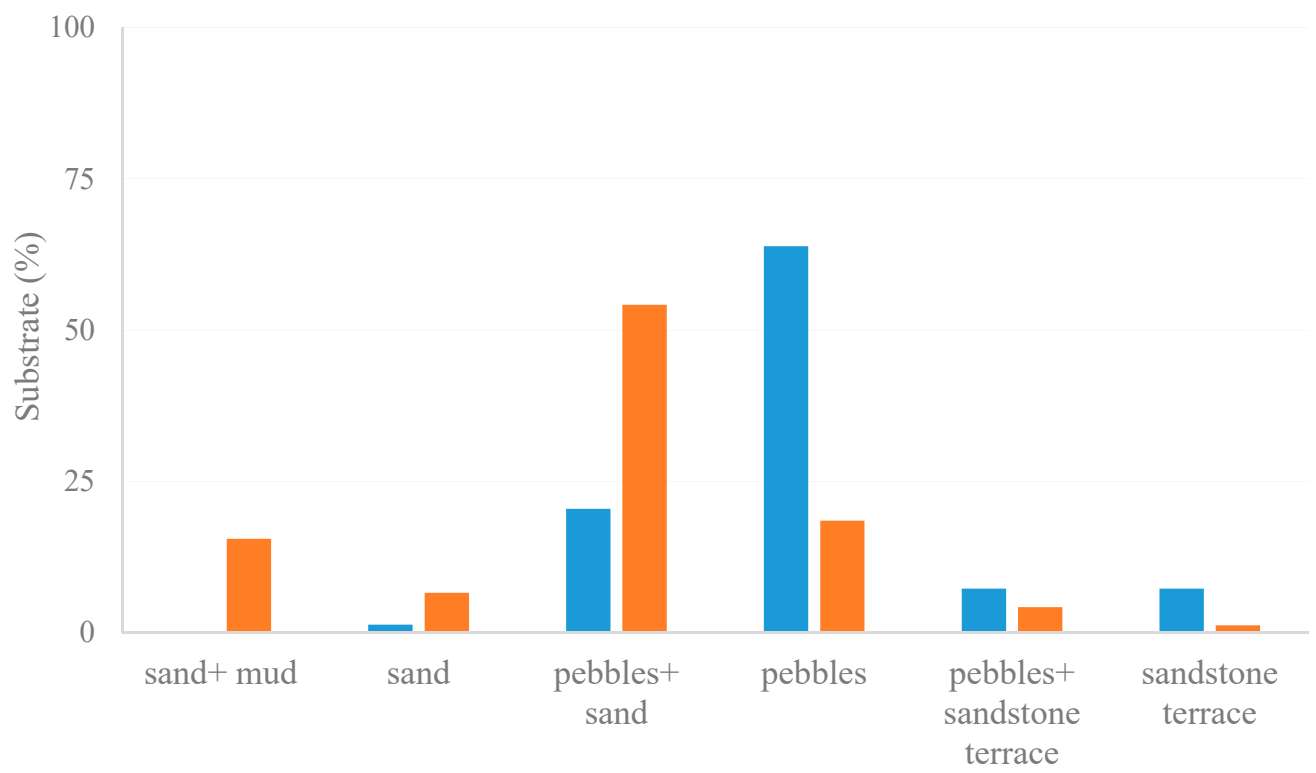

Figure 8. Substrate coverage under stones occupied by Lepadogaster lepadogaster (blue bars) and Lepadogaster candolii (orange bars).

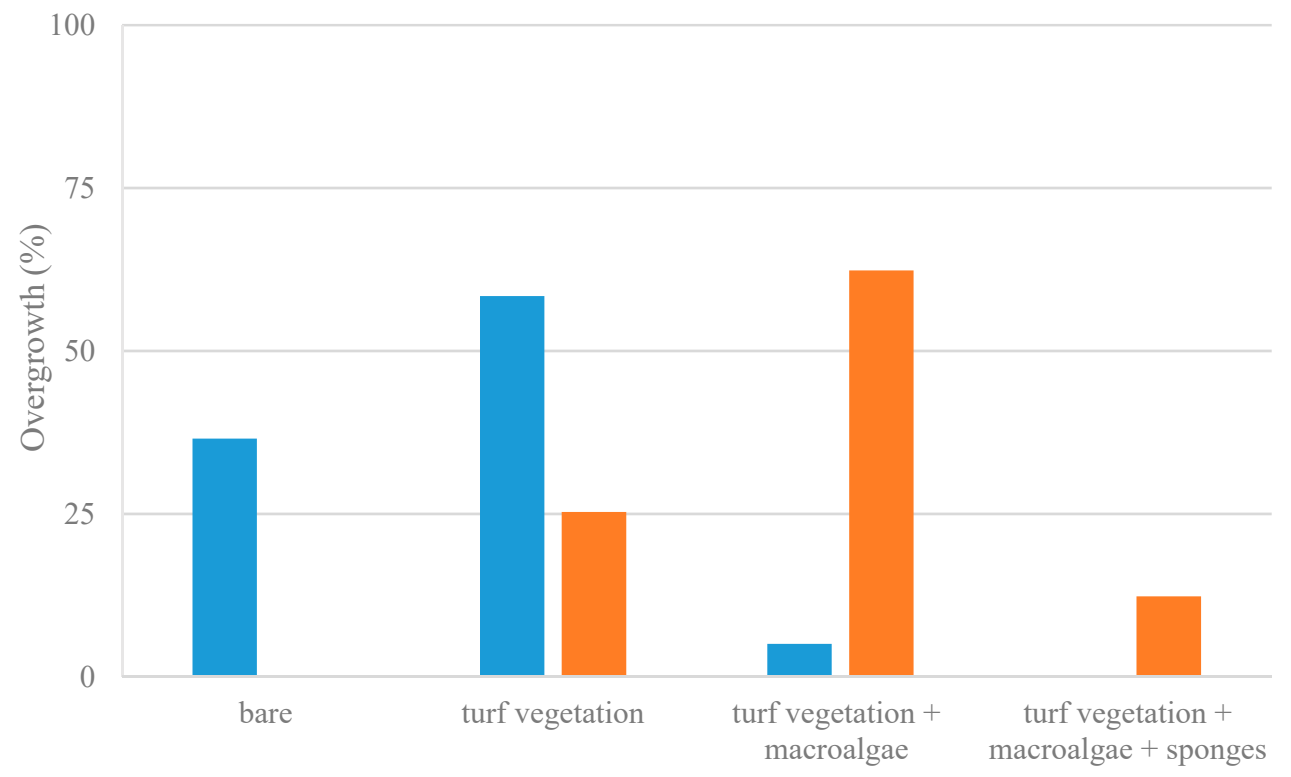

Figure 9. Overgrowth on stones occupied by Lepadogaster lepadogaster (blue bars) and Lepadogaster candolii (orange bars).

For both species, it was observed that the undersurface area was positively correlated with the fish size, as larger specimens occupied stones with larger undersurface areas (Figure 10). Furthermore, our data showed a significant linear relation $(p<\alpha ; \alpha=0.05)$ between the undersurface area and fish size for both species. The undersurface areas of the stones were rougher for $L$. candolii than L. lepadogaster due to small holes made by different excavators, and their cover was overgrown with tubes of serpulid polychaetes. 


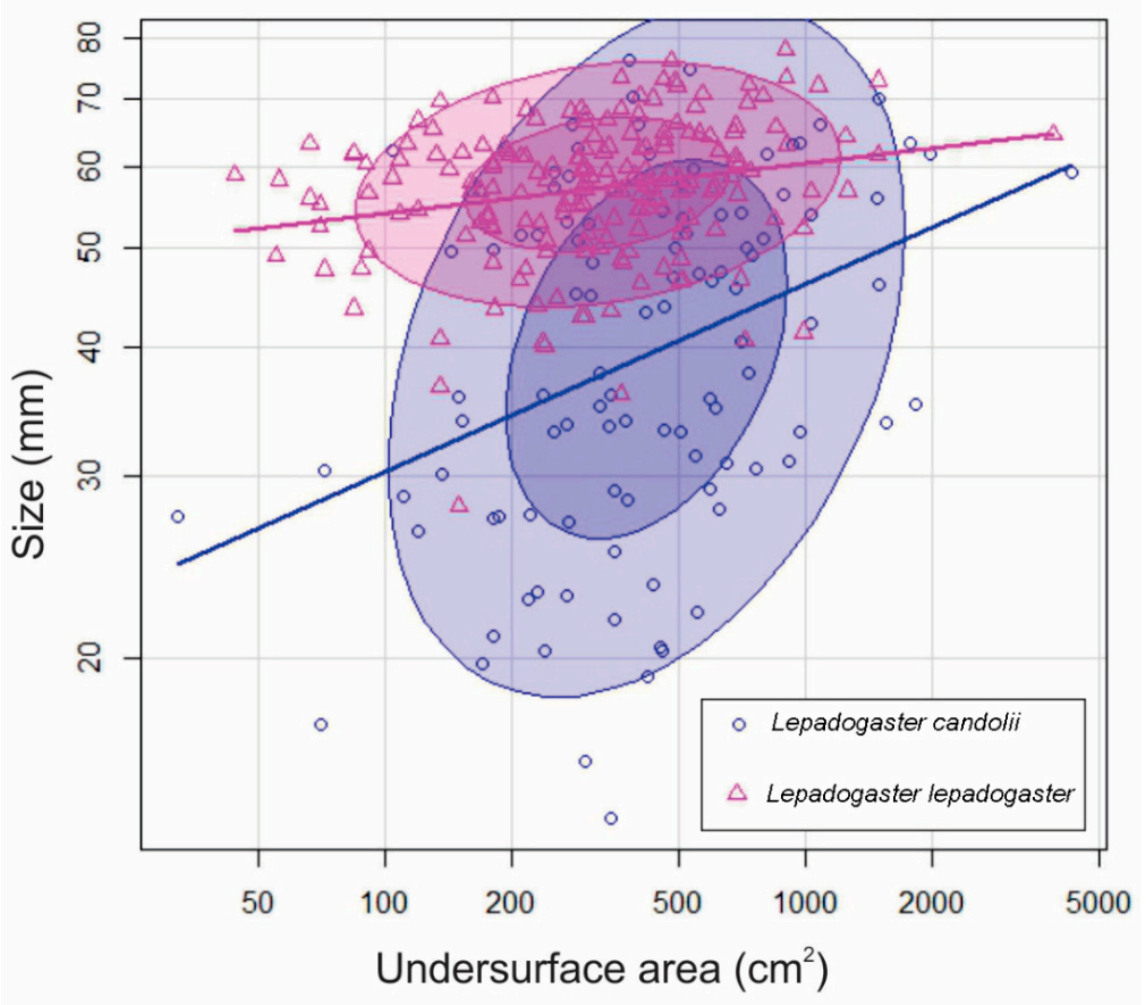

Figure 10. Ratio between the undersurface area of inhabited stones and sizes of Lepadogaster lepadogaster and Lepadogaster candolii. Inner concentration ellipses cover $50 \%$ of all data for a given species, and outer concentration ellipses cover $75 \%$ of the data for a particular species. Both axes are log-transformed.

Although specimens of $L$. candolii also occurred in seagrass meadows at the same depth as A. incognitus and both specimens occupied seashells, there were evident differences in choice of hiding place between these two species. Adult specimens of L. candolii occupied shells of dead P. nobilis lying on the sea bottom. Such pen shells were also occupied by big males of Parablennius tentacularis and Gobius niger but almost never by A. incognitus. The latter mostly hide inside empty oyster shells, which are too small for adult $L$. candolii. Furthermore, juvenile specimens of L. candolii mostly occupied the undersurface of oyster shells on the sea bottom and were almost never observed inside the shells. However, A. incognitus prefer oyster shells attached to living $P$. nobilis, which further reduces the possibility of competition with $L$. candolii and with other invertebrates and potential predators (e.g., crabs). Despite the overlap of depths and macrohabitats, the chance of an encounter or competition between individuals of two species in the same habitat is quite low when combining their depth range and microhabitat preferences.

Of all three species, A. incognitus most often occurred outside the shelter. In contrast, specimens of $L$. lepadogaster were never observed outside the shelter. Contrary to expectations, the present quantitative data on individual occurrences showed that $A$. incognitus and L. candolii are not strictly cryptobenthic species, while L. lepadogaster is.

\section{Discussion}

\subsection{Size Distribution and Sex Ratio}

All three studied species are well-adapted to the environments in which they are found. All of them are small-sized coastal fish (smaller than $10 \mathrm{~cm}$ ) or very small (A. incognitus is less than $6 \mathrm{~cm}$ long), which enables the efficient exploitation of cryptic habitats and better food availability [8]. The size of the fish species is correlated with their preferred microhabitat choice. Specimens of A. incognitus were found to effectively explore oyster shells, which are the smallest shelters compared to the other two species. The other two 
species are bigger and hide mostly under stones, where space is not so restricted. All three species are dorsoventrally flattened, which is another adaptation from exploiting their preferred cryptic habitats, where space is a limiting factor $[44,45]$. The larger body size of males of all three species could be correlated with territoriality and nest guarding, as bigger males can protect their nests more easily. This dominance rank that is positively correlated with the size of the fish was also observed in blennies, in which male territoriality and nest guarding is also known [46-48].

The sex ratio of L. lepadogaster was not significantly different from 1:1, which is in accordance with other studies [24,26]. The higher number of collected males than females of $A$. incognitus is not necessarily the result of a real population sex ratio but, rather, is related to their habitat choice; males are bigger and hide mostly in seashells, while females are smaller and can hide among seagrass leaves $[13,18]$ and other cryptic habitats where it is much harder to observe them. However, it is hard to provide a hypothesis for the higher number of female L. candolii.

\subsection{Habitat Selection Patterns in Three Clingfish Species}

\subsubsection{Species Occurrence and Abundance}

All three clingfish species were found in shallow coastal waters, where they were distinctly in conjunction with the substrate, which is typical for many clingfish species in general (sensu [24]). Of the three species, L. lepadogaster specimens were most often found, which is in accordance with many studies [21-27] reporting that this species is locally common and is considered as one of the most common clingfish species in the Mediterranean Sea.

\subsubsection{Depth Segregation}

Many coastal fish are syntopic. Separation into different ecological niches enables them to coexist in the ecosystem [49]. The separation of ecological niches is also evident in the three studied clingfish species. The three clingfish species differ in terms of depth segregation, with just a little overlap between them. The occurrence of L. lepadogaster in the lower mediolittoral and upper infralittoral is in agreement with observations by Hofrichter and Patzner [13], who reported that the species was the most abundant at a depth of $0.8 \mathrm{~m}$. However, Gibson [50] and Hofrichter [24] reported that some specimens could be found much deeper in the infralittoral (down to a 12-m depth). Hofrichter [24] noted that, for L. lepadogaster, there is no seasonal shift to deeper waters due to low winter temperatures, but he observed that the fish moved to deeper water in bad weather conditions (e.g., storms and extreme surf). The occurrence of L. candolii below the lower limit of distribution of L. lepadogaster was also observed by Brandstätter and Körbek [51]. Hofrichter and Patzner [13] reported that the species is most abundant at a depth of around $2 \mathrm{~m}$, where it reaches a maximum density of $10 \mathrm{ind} . / \mathrm{m}^{2}$. A. incognitus occurred in deeper bottoms than the other two species, which is related to the availability of seagrass meadows present in the Slovenian Sea from 1 to $11 \mathrm{~m}$ in depth [34].

The three species were segregated by changes in sea depth preferences according to the size of individuals. Furthermore, depth segregation of different sizes of fish within the same species is known in many fish species and is the result of intense intraspecific predation or competition $[52,53]$. Intraspecific depth segregation could be due to the avoidance of competition for food and shelter between specimens of different sizes, as well as the avoidance of cannibalism, since large specimens can prey on smaller specimens. The predation of large specimens of $L$. candolii on smaller ones was observed when they were kept together in a 10-L bucket (personal observation). Cannibalism is also known in other clingfishes [54,55]. Another very likely reason is that larger specimens of L. lepadogaster occurred somewhat deeper than smaller ones, which could be related to the presence of crabs (especially Pisidia sp.), which are an important source of food for large specimens [56] and occur mainly in the upper infralittoral $[57,58]$. This is also supported by the occurrence of the largest specimens of $L$. candolii, which were abundant especially in the upper 
infralittoral belt, where crabs represent important prey for them (unpublished data). The occurrence of large specimens of L. lepadogaster in the upper infralittoral could also be linked to strong territorial behavior by males [59], which hide under the same stone for several months [24]. Since specimens were never found outside of the water at low tide, specimens from the lower mediolittoral need to move somewhat deeper or remain in tide pools. Furthermore, the movement of males into slightly deeper water during the mating season was previously reported by Hofrichter [24]. In addition, the distribution of small specimens of L. lepadogaster in the upper part of the lower mediolittoral and of L. candolii in the lower infralittoral is probably also due to the avoidance of competition and to the interspecific predation of large specimens, which were most abundant in both species at the mediolittoral-infralittoral boundary. Predation by L. lepadogaster on smaller Gouania willdenowi (Risso 1810) was observed by Hofrichter [24].

L. lepadogaster and L. candolii showed similar macrohabitat preferences but with somewhat different exposures to wave action. L. lepadogaster specimens were mostly found in boulder fields and banks of large stones, where this species achieved a density of a maximum of 8 ind. $/ \mathrm{m}^{2}$ [12], while Hofrichter and Patzner [13] reported a maximum 23 ind. $/ \mathrm{m}^{2}$ in such habitats. Adaptation to strongly exposed habitats and the avoidance of calm waters, which were observed for L. lepadogaster, are also known in other clingfishes, although adequate shelter and food are provided $[54,60]$. The occurrence of L. candolii in mediolittoral in such areas shows that this species probably has different preferences for habitat exposure or just takes advantage of the free habitat niches. The preference for less turbulent water by L. candolii was previously reported by Gonçalves et al. [61]. Boulder fields were recognized as the most suitable habitat for those two species, as well as other Mediterranean clingfishes [13], by Hofrichter [18,24] and Patzner [12]. Patzner [12] noted that, in boulder fields, L. candolii can reach a maximum density of up to $12 \mathrm{ind} . / \mathrm{m}^{2}$. L. candolii also occurred in seagrass meadows, as observed by other researchers $[12,13,18]$, where it is syntopical with $A$. incognitus. Although A. incognitus mostly occurred deeper than $L$. candolii, both species were found at the same time in some locations but were collected from different hiding places.

\subsubsection{Habitat Selection}

All three clingfish species exhibit a cryptic lifestyle, which provides them with protection against predators [13]. L. lepadogaster and L. candolii show similar microhabitat preferences, as both species prefer stones of a similar size and a similar substrate under the stone. Due to a high water turbulence and factors associated with low tide, many stones occupied by L. lepadogaster were devoid of vegetation. Meanwhile, L. candolii appeared slightly deeper or in sheltered areas where conditions were more favorable for macroalgae growth, and consequently, algae were more abundant on those stones. The habit of L. lepadogaster to occupy flat stones covered with algae was previously reported by King [26], while the occurrence of L. candolii in the biocenosis of photophilic algae has been reported in other studies $[13,18,62]$, which also reported the selection of bare stones by L. lepadogaster.

L. lepadogaster and L. candolii occupied stones that were big enough that wave action could not move or turn them around but not so big that they would be heavy enough to sink into the sediment. Our results on preferred stone sizes (undersurface areas) by L. lepadogaster are in accordance with a study by Henriques et al. [9] showing that L. lepadogaster occupied stones with a similar bottom surface area $\left(477 \mathrm{~cm}^{2}\right)$. L. candolii showed a preference for larger undersurface areas than L. lepadogaster. As L. lepadogaster specimens were, on average, bigger than $L$. candolii, the size of the fish species is probably not related to the surface area of the stones. At the same time, it should be noted that the sizes of the stones decreased with the distance from the coast. One reason why L. candolii prefer stones with larger undersurface areas could be that they inhabit deeper and less turbulent waters, which means less food for potential prey (detritivore crustaceans). This may be reflected in lower prey abundances, and consequently, L. candolii needs a bigger shelter to obtain 
enough food. Another reason could be related to the substrates under stones (e.g., sand, which is more common in deeper areas), which provides less shelter for potential prey groups (especially decapods [63]) and could also be compensated by the choice of stones with larger undersurface areas. Furthermore, L. candolii also prey outside the shelter, as observed by Gonçalves et al. [61], which could be due to an insufficient amount of suitable prey under the stones. Conversely, specimens of L. lepadogaster were not observed outside the shelter, which is in accordance with observations of many researchers (e.g., [18,24,61]). Gonçalves et al. [61] noted that L. lepadogaster does not make many movements, probably due to the turbulent environment in which it lives. An association between little movement and a turbulent environment was also observed in blennies [64]. Velasco et al. [65] noted that, in the rocky intertidal habitat, the availability of prey is relatively high, which is reflected in a higher dietary overlap of intertidal fish. Furthermore, a high density of suitable prey could be an important factor, as it allows feeding without major movement. These observations indicate that $L$. lepadogaster exhibit the most exclusive cryptic behavior compared to L. candolii, which was previously confirmed in other studies, while A. incognitus is even less strict in cryptobenthic occurrence than L. candolii $[18,24,61]$. The present research shows that the degree of cryptic behavior of cryptobenthic fishes should be concluded from quantitative data, e.g., from observations of the microhabitat positions of a large number of individuals, and not presumed in advance or from qualitative data and individual observations.

The sizes of L. lepadogaster and L. candolii were found to be positively correlated with the undersurface area of the stones, as larger specimens preferred larger surface areas. The reason for the intraspecific occupation of stones with a larger undersurface area by large specimens could be that they offer more space, as well as a larger area in which to search for prey.

L. lepadogaster and L. candolii showed a preference for similar substrates under occupied stones. For both species, pebbles were the most common substrate. Pebbles probably provide enough space under stones for clingfish specimens to live under them. Furthermore, pebbles are a favorite habitat for decapods Pisidia sp. and A. nitescens [63], as well as isopods and amphipods, which are important food items for clingfishes $[26,50,56,65,66]$. However, under stones occupied by L. candolii, pebbles were usually mixed with sand. This is probably related to the depth, since. L. candolii occur in deeper waters distant from the coast, where finer sediments are more prevalent. In the case where only fine substrate (e.g., sand) was present under the stones, there was usually not enough space between the stone and the substrate (stones were usually sunken) for the clingfish, while big stones as substrates cause the hiding place underneath to be too exposed and offer no protection against predators.

Specimens of L. candolii also occupied seashells (mostly P. nobilis and O. edulis) and artificial structures. L. candolii exploited these microhabitats mostly in seagrass meadows, where shells are almost the only hard remains that can be used for shelter, so their availability is a limiting factor. Artificial structures such as metal and plastic plates can be used as alternative shelters. The exploitation of artificial structures as hiding places by L. candolii and Diplecogaster bimaculata, a related species, was also reported by Brandl et al. [19]. Most of the stones on the sedimentary bottom near the coast are also the result of human activities (stones thrown by people). However, most of these are unsuitable for clingfish occupation, as they sunk into the seabed due to their weight. Under such stones, specimens of Gobius niger (Linnaeus 1758) were mostly observed, which can dig shelters under stones. G. niger and big males of Parablennius tentacularis (Brünnich 1768) were the most common fish species observed under shells of dead P. nobilis. As each shell is usually occupied by only one fish, we can assume there is ongoing interspecific competition for such shelters. Strong intra- and interspecific competitions for shelter, which limit resources in the environment, were already demonstrated in blennies $[46,47,67,68]$.

The presence of specimens of $L$. candolii outside the shells of $P$. nobilis confirms that they move around outside the shelter, which was already suspected by Kovačić [62] and 
reported by other researchers $[13,18,61]$. However, the specimens were never observed freely swimming between shelters in the field, as some authors reported [12,13], except when they were disturbed from the shelter. In that case, specimens sometimes swam more than $1 \mathrm{~m}$ to the next shelter, not necessarily the nearest one, as was observed in L. lepadogaster.

Some researchers $[13,18,30]$ reported that juvenile and subadult specimens of $A$. incognitus were commonly found on leaves of $P$. oceanica and under different species of sea urchins, where they reached a maximum abundance of up to $40 \mathrm{ind} . / \mathrm{m}^{2}$. However, in this study, specimens of $A$. incognitus and L. candolii were never found under sea urchins, even though these hiding places were checked many times. In fact, this is the first study to show the preference of adult specimens of $A$. incognitus for empty oyster shells attached to $P$. nobilis. A flattened body and small body size enable them to effectively occupy dead oyster shells. However, the oyster shells are also inhabited by other fish species, such as small specimens of P. tentacularis, Symphodus cinereus, and Zebrus zebrus (personal observation). This may indicate that there is competition for shelter between certain coastal fish. However, it seems that $A$. incognitus prefers empty oyster shells, which are less open than those occupied by $P$. tentacularis, especially during the nesting period. The occupation of such shells is possible due to their smaller body height, which is, besides Blenniidae and Gobiidae, the most pronounced in Gobiesocidae [44,45]. This gives A. incognitus a competitive advantage in exploiting such hiding places. Furthermore, adult males of A. incognitus have wide heads in the cheek area [18], which makes them seem bigger from a frontal view. Having a disproportionally wide mouth for their body size, they display their caniniform teeth, which probably serve for defense, as they are not used for feeding. Many other small territorial fish species also have big caniniform teeth that are not used for feeding but, rather, for deterring predators and displaying during antagonistic interactions [69]. Teeth displays (yawning) were observed in the interactions of specimens of all three species kept in the aquariums (unpublished data), and such behavior was also observed in L. lepadogaster by Hofrichter [24].

\section{Conclusions}

Marine fish are involved in many critical ecosystem processes and provide a variety of ecosystem goods and services [70]. Research on cryptobenthic fish species is thus essential in order to understand the functioning of the marine ecosystem. Due to their cryptic way of life, their importance was usually overlooked in the past. However, new discoveries about cryptobenthic fish species show that they represent an essential part of coastal biodiversity and can importantly affect ecosystem functions [15]. Knowledge about the ecology of small cryptobenthic gobies and gobiesocids from the Mediterranean Sea is still insufficient [12], and studies like the present research are still rare.

Habitat loss and fragmentation are major threats to biodiversity [71] and, also, the biggest threat to cryptobenthic fish communities [72]. Cryptobenthic fish species with specific habitat preferences are usually the most vulnerable to changes of microhabitats, even if some species show plasticity in habitat use [73]. Cryptobenthic fishes in general have a small dispersal range (due to the small body size $[55,72,74]$ ), so they can be affected by the fragmentation of a suitable habitat, making it difficult for them to recolonize [72]. Habitat degradation is also very problematic in the Slovenian part of the Adriatic Sea, especially in the coastal part, as less than $20 \%$ of it is still in a natural state. As the most degraded parts are coastal zones of the supralittoral, mediolittoral, and infralittoral [75], this has a big impact on L. lepadogaster, which exclusively occupies this coastal zone. Due to the specific habitat requirements of L. lepadogaster and isolated locally abundant populations, a serious disturbance of habitats and specimens in their collection might seriously affect their populations [26].

In recent years, seagrass meadows have been disappearing not only along the Slovenian coast [34] but, also, in other parts of the Mediterranean Sea and the Atlantic Ocean [76,77]. Furthermore, in the Mediterranean Sea, there is high mortality of P. nobilis [78], whose 
population is declining, and the species is now considered to be critically endangered [79]. P. nobilis is an important bioconstructor, since its big shell offers shelter or a solid basis for the settlement of many other organisms [78,80,81]. Among them, empty oyster shells offer important shelters and nests for $A$. incognitus. The decline of $P$. nobilis and seagrass meadows can have a significant impact on populations of $A$. incognitus and other fish species that are strongly associated with them. Among the three species, it seems that $L$. candolii is the least negatively affected by human activities. This is due to its distribution in the infralittoral belt, which is less affected by humans, its euryecious habitat and microhabitat preferences, and even its potential to use artificial objects on the sea bottom as shelter.

Author Contributions: Conceptualization, D.T. and L.L.; methodology, D.T., L.L. and M.K.; software, D.I. and D.T.; validation, D.I.; formal analysis, D.I.; investigation, D.T. and L.L.; resources, D.T. and L.L.; data curation, D.T., L.L. and D.I.; writing-original draft preparation, D.T.; writing-review and editing, L.L., M.K. and D.I.; visualization, D.T., L.L., M.K. and D.I; supervision, L.L.; project administration, L.L.; and funding acquisition, L.L. All authors have read and agreed to the published version of the manuscript.

Funding: This research was funded by the Slovenian Research Agency.

Institutional Review Board Statement: The specimens investigated in this study were handled with the least stress possible and released in the same environment where they were caught as soon as all measurements were taken. The specimens from the National Institute of Biology (MBS) collection were sampled following the national regulations dealing with scientific investigations.

Informed Consent Statement: Not applicable.

Data Availability Statement: The data presented in this study are available on request from the corresponding author.

Acknowledgments: We would like to express our gratitude to our coworkers Tihomir Makovec, Ana Fortič, Borut Mavrič, and Žiga Dobrajc, who helped us with the field work, and Martina Orlando Bonaca for her immense and continuous support.

Conflicts of Interest: The authors declare no conflict of interest.

\section{References}

1. Cañadas, A.; Sagarminaga, R.; De Stephanis, R.; Urquiola, E.; Hammond, P.S. Habitat Preference Modelling as a Conservation Tool: Proposals for Marine Protected Areas for Cetaceans in Southern Spanish Waters. Aquat. Conserv. Mar. Freshw. Ecosyst. 2005, 15, 495-521. [CrossRef]

2. Huey, R.B. Physiological Consequences of Habitat Selection. Am. Nat. 1991, 137, S91-S115. [CrossRef]

3. Franklin, A.B.; Anderson, D.R.; Gutiérrez, R.J.; Burnham, K.P. Climate, Habitat Quality, and Fitness in Northern Spotted Owl Populations in Northwestern California. Ecol. Monogr. 2000, 70, 539-590. [CrossRef]

4. Crowe, T.P.; Underwood, A.J. Testing Behavioural “preference" for Suitable Microhabitat. J. Exp. Mar. Biol. Ecol. 1998, 225, 1-11. [CrossRef]

5. Brooker, R.M.; Munday, P.L.; Mcleod, I.M.; Jones, G.P. Habitat Preferences of a Corallivorous Reef Fish: Predation Risk versus Food Quality. Coral Reefs 2013, 32, 613-622. [CrossRef]

6. Mittelbach, G.G. Foraging Efficiency and Body Size: A Study of Optimal Diet and Habitat Use by Bluegills. Ecology 1981, 62, 1370-1386. [CrossRef]

7. Gilliam, J.F.; Fraser, D.F. Habitat Selection Under Predation Hazard: Test of a Model with Foraging Minnows. Ecology 1987, 68, 1856-1862. [CrossRef] [PubMed]

8. Miller, P.J. Adaptiveness and Implications of Small Size in Teleosts. Symp. Zool. Soc. Lond. 1979, 44, $263-306$.

9. Henriques, M.; Lourenco, R.; Almada, F.; Calado, G.; Goncalves, D.; Guillemaud, T.; Cancela, M.L.; Almada, V.C. A Revision of the Status of Lepadogaster lepadogaster (Teleostei: Gobiesocidae): Sympatric Subspecies or a Long Misunderstood Blend of Species? Biol. J. Linn. Soc. 2002, 76, 327-338. [CrossRef]

10. Smith-Vaniz, W.F.; Jelks, H.L.; Rocha, L.A. Relevance of Crypticfishes in the Biodiversity Assessments: A Case Study at Buck Island Reef National Monument, St. Croix. Bull. Mar. Sci. 2006, 79, 17-48.

11. Miller, P.J. Gobiidae. In Fishes of the North-Eastern Atlantic and the Mediterranean; Whitehead, P.J.P., Bauchot, M.-L.H., Nielsen, J.-C., Tortonese, J.E., Eds.; UNESCO: Paris, France, 1986; pp. 1019-1085.

12. Patzner, R.A. Habitat Utilization and Depth Distribution of Small Cryptobenthic Fishes (Blenniidae, Gobiesocidae, Gobiidae, Tripterygiidae) in Ibiza (Western Mediterranean Sea). Environ. Biol. Fishes 1999, 55, 207-214. [CrossRef] 
13. Hofrichter, R.; Patzner, R.A. Habitat and Microhabitat of Mediterranean Clingfishes (Teleostei: Gobiesociformes: Gobiesocidae). Mar. Ecol. 2000, 21, 41-53. [CrossRef]

14. Glavičić, I.; Paliska, D.; Soldo, A.; Kovačić, M. A Quantitative Assessment of the Cryptobenthic Fish Assemblage at Deep Littoral Cliffs in the Mediterranean. Sci. Mar. 2016, 80, 329-337. [CrossRef]

15. Ackerman, J.L.; Bellwood, D.R. Reef Fish Assemblages: A Re-Evaluation Using Enclosed Rotenone Stations. Mar. Ecol. Prog. Ser. 2000, 206, 227-237. [CrossRef]

16. Ackerman, J.L.; Bellwood, D.R. Comparative Efficiency of Clove Oil and Rotenone for Sampling Tropical Reef Fish Assemblages. J. Fish Biol. 2002, 60, 893-901. [CrossRef]

17. Depczynski, M.; Bellwood, D.R. The Role of Cryptobenthic Reef Fishes in Coral Reef Trophodynamics. Mar. Ecol. Prog. Ser. 2003 256, 183-191. [CrossRef]

18. Hofrichter, R. Taxonomie, Verbreitung und Ökologie von Schildfischen der Unterfamilie Lepadogastrinae (Gobiesocidae, Teleostei). Ph.D. Thesis, University of Salzburg, Salzburg, Austria, 1995.

19. Brandl, S.J.; Wagner, M.; Hofrichter, R.; Patzner, R.A. First Record of the Clingfish Apletodon dentatus (Gobiesocidae) in the Adriatic Sea and a Description of a Simple Method to Collect Clingfishes. Bull. Fish Biol. 2011, 13, 65-69.

20. Wheeler, A. The Fishes of the British Isles and North-West Europe; Macmillan: London, UK, 1969.

21. Briggs, J.C. Gobiesocidae. In Check List of the North-Eastern Atlantic and of the Mediterranean; Hureau, J.C., Monod, T., Eds.; UNESCO: Paris, France, 1986; pp. 651-656.

22. Briggs, J.C. Gobiesocidae. In Check List of the Fisches of the Eastern Tropical Atlantic; Metivier, C., Sanchez-Jaimes, J., Eds.; UNESCO: Lisbon, Portugal, 1990; pp. 474-478.

23. Dunne, J. Gobiesocidae Occuring in the Coastal Waters of Connemara. Ir. Fish. Invest. 1983, 23, 32-36.

24. Hofrichter, R. Beitrag zur Kenntnis der Mediterranen Schildfische (Teleostei, Gobiesocidae) mit Besonderer Berücksichtigung der Fortpflanzung von Lepadogaster lepadogaster. Master's Thesis, University of Salzburg, Salzburg, Austria, 1993.

25. Illich, I.P.; Kotrschal, K. Depth Distribution and Abundance of Northern Adriatic Littoral Rocky Reef Blennioid Fishes (Blenniidae and Tripterygion). Mar. Ecol. 1990, 11, 277-289. [CrossRef]

26. King, P.A. Littoral and Benthic Investigations on the West Coast of Ireland: XXII, The Biology of a Population of Shore Clingfish Lepadogaster lepadogaster (Bonnaterre, 1788) at Inishbofin, Co. Galway. Proc. R. Ir. Acad. B. 1989, 89, 47-58.

27. Wilson, J.P.F. A Note on the Biology of the Cornish Clingfish Lepadogaster lepadogaster (Bonnaterre). Irish Nat. J. 1981, 20, 209-210.

28. Kovačić, M.; Patzner, R.A.; Schliewen, U. A First Quantitative Assessment of the Ecology of Cryptobenthic Fishes in the Mediterranean Sea. Mar. Biol. 2012, 159, 2731-2742. [CrossRef]

29. Hofrichter, R.; Patzner, R.A. A New Species of Apletodon from the Mediterranean Sea and the Eastern Atlantic with Notes on the Differentiation between Apletodon and Diplecogaster Species (Pisces: Teleostei: Gobiesociformes: Gobiesocidae). Senckenb. Biol. 1997, 77, 15-22.

30. Patzner, R.A.; Santo, R.S. Field Observations on the Association Between the Clingfish Diplecogaster bimaculata pectoralis Briggs, 1955 and Different Species of Sea Urchins at the Azores. Z. Fischk. 1992, 1, 157-161.

31. Bilecenoglu, M.; Kaya, M. The Occurrence of Apletodon incognitus Hofrichter \& Patzner, 1997 (Gobiesocidae) in the Eastern Mediterranean Sea. Acta Ichthyol. Piscat. 2006, 36, 143-145.

32. Louisy, P. Europe and Mediterranean Marine Fish Identification Guide; Les Éditions Eugen Ulmer: Paris, France, 2015.

33. Ogorelec, B.; Mišič, M.; Faganeli, J. Marine Geology of the Gulf of Trieste (Northern Adriatic): Sedimentological Aspects. Mar. Geol. 1991, 99, 79-92. [CrossRef]

34. Lipej, L.; Ivajnšič, D.; Makovec, T.; Mavrič, B.; Šiško, M.; Trkov, D.; Orlando-Bonaca, M. Raziskava z Oceno Stanja Morskih Travnikov v Krajinskem Parku Strunjan; Marine Biology Station Piran, National Institute of Biology: Piran, Slovenia, 2018.

35. Gibson, R.N. The Use of the Anaesthetic Quinaldine in Fish Ecology. J. Anim. Ecol. 1967, 36, 301. [CrossRef]

36. Wagner, M.; Bračun, S.; Skofitsch, G.; Kovačić, M.; Zogaris, S.; Iglésias, S.P.; Sefc, K.M.; Koblmüller, S. Diversification in Gravel Beaches: A Radiation of Interstitial Clingfish (Gouania, Gobiesocidae) in the Mediterranean Sea. Mol. Phylogenet. Evol. 2019, 139, 106525. [CrossRef] [PubMed]

37. Ličer, M.; Fettich, A.; Jeromel, M. Prognozirano Plimovanje Morja Tide Tables 2018; Ministry of the Environment and Spatial Planning, Slovenian Environment Agency: Ljubljana, Slovenia, 2018.

38. Ličer, M.; Fettich, A.; Jeromel, M. Prognozirano Plimovanje Morja Tide Tables 2019; Ministry of the Environment and Spatial Planning, Slovenian Environment Agency: Ljubljana, Slovenia, 2019.

39. Ličer, M.; Fettich, A.; Jeromel, M. Prognozirano Plimovanje Morja Tide Tables 2017; Ministry of the Environment and Spatial Planning, Slovenian Environment Agency: Ljubljana, Slovenia, 2017.

40. Jardas, I. Jadranska Ihtiofauna; Školska knjiga: Zagreb, Croatia, 1996.

41. Marčeta, B. Osteichthyes. In Key for Determination of Vertebrates in SLOVENIA; Kryštufek, B., Janžekovič, F., Eds.; DZS: Ljubljana, Slovenia, 1999; pp. 47-210.

42. Wagner, M.; Bračun, S.; Kovačić, M.; Iglésias, S.P.; Sellos, D.Y.; Zogaris, S.; Koblmüller, S. Lepadogaster purpurea (Actinopterygii: Gobiesociformes: Gobiesocidae) from the Eastern Mediterranean Sea: Significantly Extended Distribution Range. Acta Ichthyol. Piscat. 2017, 47, 417-421. [CrossRef]

43. R Development Core Team. A Language and Environment for Statistical Computing. R Foundation for Statistical Computing: Vienna, Austria, 2020; Available online: http:/ / www.R-project.org (accessed on 10 April 2021). 
44. Abel, E.F. Freiwasserbeobachtungen an Fischen Im Golf von Neapel als Beitrag zur Kenntnis Ihrer Ökologie und Ihres Verhaltens. Int. Rev. Der Gesamten Hydrobiol. Und Hydrogr. 1962, 47, 219-290. [CrossRef]

45. Gibson, R.N. The Biology and Behaviour of Littoral Fish. Ocean. Mar. Biol. Ann. Rev. 1969, 7, 367-410.

46. Orlando-Bonaca, M.; Lipej, L. Utilization of Empty Holes by Two Adriatic Endolithic Blennies under Experimental ConditionsPreliminary Results. Ann. Ser. Hist. Nat. 2008, 18, 179-190.

47. Trkov, D. Znotrajvrstni in Medvrstni Odnosi...Mediolitoralnih Babic (Blenniidae) Tržaškega Zaliva. Master's Thesis, Univerza na Primorskem, Fakulteta za Matematiko, Naravoslovje in Informacijske Tehnologije, Koper, Slovenia, 2014.

48. Lengkeek, W. Dynamic Reproductive Behaviour and the Evolution of Sex Size Dimorphism in Mediterranean Blennies. Ph.D. Thesis, University of East Anglia, Norwich, England, 2006.

49. Zander, C.D.; Berg, J. Feeding Ecology of Littoral Gobiid and Blennioid Fishes of the Banyuls Area (Mediterranean Sea). II: Prey Selection and Size Preference. Vie Milieu 1984, 34, 149-157.

50. Gibson, R.N. The Vertical Distribution and Feeding Relationships of Intertidal Fish on the Atlantic Coast of France. J. Anim. Ecol. 1972, 41, 189-207. [CrossRef]

51. Brandstätter, R.; Körbek, R. Biologie Der Saugfische: 1. Habitat, Verbreitung und Nahrung. BUFUS Info. Zool. Salzbg. 1989, 5, 27-29.

52. Guttridge, T.L.; Gruber, S.H.; Franks, B.R.; Kessel, S.T.; Gledhill, K.S.; Uphill, J.; Krause, J.; Sims, D.W. Deep Danger: Intra-Specific Predation Risk Influences Habitat Use and Aggregation Formation of Juvenile Lemon Sharks Negaprion brevirostris. Mar. Ecol. Prog. Ser. 2012, 445, 279-291. [CrossRef]

53. Freeman, M.C.; Stouder, D.J. Intraspecific Interactions Influence Size Specific Depth Distribution in Cottus bairdi. Environ. Biol. Fishes 1989, 24, 231-236. [CrossRef]

54. Johnson, C.R. Notes on the Intertidal Life History of the Northern Clingfish, Gobiesox maeandricus (Girard). Am. Midl. Nat. 1970, 83, 625. [CrossRef]

55. Pires, T.H.S.; Gibran, F.Z. Intertidal Life: Field Observations on the Clingfish Gobiesox barbatulus in Southeastern Brazil. Neotrop. Ichthyol. 2011, 9, 233-240. [CrossRef]

56. Trkov, D.; Lipej, L. A Non-Destructive Method for Assessing the Feeding Habits of Coastal Fish. Mediterr. Mar. Sci. 2019, 20, 453-459. [CrossRef]

57. Holthuis, L.B. Report on a Collection of Crustacea Decapoda and Stomatopoda from Turkey and the Balkans. Zool. Verh. Leiden. 1961, 47, 1-67.

58. Melzer, R.; Ceseña, F.; Buršić, M.; Lehmann, T.; Mayer, R.; Mavrič, B.; Makovec, T.; Pfannkuchen, M.; McHenry, J.; Heß, M. Knights, Ballerinas and Invisibles: The Decapod Crustaceans of the Brijuni Marine Protected Area = Vitezovi, Balerine i Nevidljivi: Rakovi Deseteronošci Zaštićenog Morskog Područja Nacionalnog Parka Brijuni; Javna ustanova Nacionalni park Brijuni: Pula, Croatia, 2019.

59. Gonclalves, E.J.; Almada, V.C.; Almeida, S.P.; Gonclalves, D.M.; Repas, M.; Simoes, N. Observations on the Agonistic Behaviour of Lepadogaster lepadogaster purpurea (Pisces: Gobiesocidae). J. Fish Biol. 1996, 49, 367-369. [CrossRef]

60. Paine, R.T.; Palmer, A.R. Syciases Sanguineus: A Unique Trophic Generalist from the Chilean Intertidal Zone. Copeia 1978, 1, 75-81. [CrossRef]

61. Gonçalves, D.M.; Gonçalves, E.J.; Almada, V.C.; Almeida, S.P. Comparative Behaviour of Two Species of Lepadogaster (Pisces: Gobiesocidae) Living at Different Depth. J. Fish Biol. 1998, 53, 447-450. [CrossRef]

62. Kovačić, M. Cryptobenthic Gobies (Pisces, Perciformes, Gobiidae) and Clingfishes (Pisces, Gobiesociformes, Gobiesocidae) in the Kvarner Area, Adriatic Sea. Nat. Croat. 1997, 6, 423-435.

63. Pallas, A.; Garcia-Calvo, B.; Corgos, A.; Bernardez, C.; Freire, J. Distribution and Habitat Use Patterns of Benthic Decapod Crustaceans in Shallow Waters: A Comparative Approach. Mar. Ecol. Prog. Ser. 2006, 324, 173-184. [CrossRef]

64. Almada, V.C.; Santos, R.S. Parental Care in the Rocky Intertidal: A Case Study of Adaptation and Exaptation in Mediterranean and Atlantic Blennies. Rev. Fish Biol. Fish. 1995, 5, 23-37. [CrossRef]

65. Velasco, E.M.; Gómez-Cama, M.C.; Hernando, J.A.; Soriguer, M.C. Trophic Relationships in an Intertidal Rockpool Fish Assemblage in the Gulf of Cádiz (NE Atlantic). J. Mar. Syst. 2010, 80, 248-252. [CrossRef]

66. Mazé, R.A. Estudio de La Dieta de Las Poblaciones Intermareales de Dos Especies de Lepadogaster (Teleostei, Gobiesocidae) En La Costa Cantábrica, España. Boletín La Real Soc. Española Hist. Nat. Sección Biológica. 2007, 102, 85-92.

67. Koppel, V.H. Habitat Selection and Space Partitioning among Two Mediterranean Blenniid Species. Mar. Ecol. 1988, 9, 329-346. [CrossRef]

68. Orlando-Bonaca, M. Izbira Mikrohabitatov pri Obrežni Favni Babic v Tržaškem Zalivu. Ph.D. Thesis, Univerza v Mariboru, Maribor, Slovenia, 2006.

69. Kotrschal, K.; Goldschmid, A. Morphological Evidence for the Biological Role of Caniniform Teeth in Combtooth Blennies (Blenniidae, Teleostei). J. Fish Biol. 1992, 41, 983-991. [CrossRef]

70. Mora, C. Ecology of Fishes on Coral Reefs; Cambridge University Press: Cambridge, UK, 2015.

71. Fahrig, L. Relative Effects of Habitat Loss and Fragmentation on Population Extinction. J. Wildl. Manag. 1997, 61, 610. [CrossRef]

72. Brandl, S.J.; Goatley, C.H.R.; Bellwood, D.R.; Tornabene, L. The Hidden Half: Ecology and Evolution of Cryptobenthic Fishes on Coral Reefs. Biol. Rev. 2018, 93, 1846-1873. [CrossRef]

73. Taylor, M.S.; Van Tassell, J.L. Observations on Microhabitat Utilization by Three Widely Distributed Neotropical Gobies of the Genus Elacatinus. Copeia 2002, 2002, 1134-1136. [CrossRef] 
74. Luiz, O.J.; Allen, A.P.; Robertson, D.R.; Floeter, S.R.; Kulbicki, M.; Vigliola, L.; Becheler, R.; Madin, J.S. Adult and Larval Traits as Determinants of Geographic Range Size among Tropical Reef Fishes. Proc. Natl. Acad. Sci. USA 2013, 110, 16498-16502. [CrossRef]

75. Turk, R. An Assessment of the Vulnerability of the Slovene Coastal Belt and Its Categorisation in View of (in) Admissible Human Pressure, Various Activities, and Land Use. Ann. Ser. Hist. Nat. 1999, 15, 37-50.

76. Pergent, G.; Bazairi, H.; Bianchi, C.N.; Boudouresque, C.F.; Buia, M.C.; Calvo, S.; Clabaut, P.; Harmelin-Vivien, M.; Angel Mateo, M.; Montefalcone, M.; et al. Climate Change and Mediterranean Seagrass Meadows: A Synopsis for Environmental Managers. Mediterr. Mar. Sci. 2014, 15, 462-473. [CrossRef]

77. Telesca, L.; Belluscio, A.; Criscoli, A.; Ardizzone, G.; Apostolaki, E.T.; Fraschetti, S.; Gristina, M.; Knittweis, L.; Martin, C.S.; Pergent, G.; et al. Seagrass Meadows (Posidonia oceanica) Distribution and Trajectories of Change. Sci. Rep. 2015, 5, 1-14. [CrossRef]

78. Cabanellas-Reboredo, M.; Vázquez-Luis, M.; Mourre, B.; Álvarez, E.; Deudero, S.; Amores, Á.; Addis, P.; Ballesteros, E.; Barrajón, A.; Coppa, S.; et al. Tracking a Mass Mortality Outbreak of Pen Shell Pinna nobilis Populations: A Collaborative Effort of Scientists and Citizens. Sci. Rep. 2019, 9, 1-11. [CrossRef] [PubMed]

79. Kersting, D.; Mouloud, B.; Cizmek, H.; Grau, A.; Jimenez, C.; Katsanevakis, S.; Oztürk, B.; Tuncer, S.; Tunesi, L.; Vázquez-Luis, M.; et al. Pinna Nobilis. IUCN Red List Threat. Species 2019; IUCN Red List: London, UK, 2019. [CrossRef]

80. Lipej, L.; Mavrič, B.; Orlando-Bonaca, M. Analiza Kriptobentoških Mikrohabitatov V Slovenskem Morju in Opredelitev Njihove Vloge Pri Ocenjevanju Stanja Biotske Raznovrstnosti Morskega Obrežnega Pasu; Marine Biology Station Piran, National Institute of Biology: Piran, Slovenia, 2012.

81. Giacobbe, S. Epibiontic Mollusc Communities on Pinna nobilis L. (Bivalvia, Mollusca). J. Nat. Hist. 2002, 36, 1385-1396. [CrossRef] 